\title{
Retraction Note to: Molecular Cloning of an Amino Acid Permease Gene and Structural Characterization of the Protein in Common Bean (Phaseolus vulgaris L.)
}

\author{
Nibedita Chakraborty $^{1,2} \cdot$ Alfred Besra $^{1} \cdot$ Jolly Basak $^{1}$ (1)
}

Published online: 6 October 2020

(c) Springer Science+Business Media, LLC, part of Springer Nature 2020

\section{Retraction to: \\ Molecular Biotechnology (2020) 62:210-217 https://doi.org/10.1007/s12033-020-00240-4}

The Editor-in-Chief has retracted this article [1]. Some concerns were raised after publication, and subsequent post publication peer review concluded that only a partial sequence of the AAP protein was used for bioinformatics analysis. As the amino acid binding domain of AAP was not completely covered in the truncated polypeptide the authors studied, the deduced structure has no biological significance. The Editor-in-Chief has invited the authors to submit a revised

Nibedita Chakraborty and Alfred Besra have contributed equally to this work.

The original article can be found online at https://doi.org/10.1007/ s12033-020-00240-4.

Jolly Basak

jolly.basak@visva-bharati.ac.in

1 Genomics of Plant Stress Biology Laboratory, Department of Biotechnology, Visva-Bharati, Santiniketan, India

2 Present Address: Department of Biotechnology, National Institute of Technology, Durgapur, West Bengal, India manuscript which will undergo peer review. All authors agree to this retraction.

\section{Reference}

1. Chakraborty, N., Besra, A., \& Basak, J. (2020). Molecular Cloning of an Amino Acid Permease Gene and Structural Characterization of the Protein in Common Bean (Phaseolus vulgaris L.). Molecular Biotechnology, 62, 210-217. https://doi.org/10.1007/ s12033-020-00240-4.

Publisher's Note Springer Nature remains neutral with regard to jurisdictional claims in published maps and institutional affiliations. 